平良勝已 比嘉見城中央病院外科

血管造影検查で術前に診断しえた大網のみを内容とする Morgagni 孔ヘルニアの 1 例 を経験したので報告する. 症例は 64 瓷, 女性. 住民検診で縦隔腫瘍を疑われ当院に紹介 された．胸部 X 線で右心臟横隔膜角に手拳大の腫瘤影を認めた．胸部 CT で胸骨後部の 心陰影の右側に接して脂肪濃度の腫瘤影を認めた. 胸部 MRI 矢状断で心膜と前胸壁に接 して腹腔内と連続する脂肪濃度の腫瘤影を認めた．Morgagni 孔へルニアが疑われたが， 維隔腫瑒も否定できないため血管造影検查を施行した，腫瘤影へ走行する右胃大網動脈 の大網枝が確認できた．以上より大網のみを内容とする Morgagni 孔へルニアと診断し 手術を行った．手術は経腹的に大網を還納し，ヘルニア亳を腹腔内へ反転切離後、ヘル ニア門を閉鎖した．本症の診断に血管造影検査が有用であると考えられた.

索引用語：Morgagni 孔ヘルニア, 血管造影検査, 大網ヘルニア

\section{緒 言}

大網のみを内容とする Morgagni 孔ヘルニアの術前 診断は従来困難とされていた．今回われわれは，血管 造影検查で術前に診断しえた Morgagni 孔へルニアの 1 例を経験したので若干の文献的考察を加えて報告す る.

\section{症例}

患者：64 歳, 女性.

主訴：咳濑, 胸部不快感.

家族歴：特記すべきことなし.

既往歴：特記すべきことなし.

現病歴: 平成 4 年 6 月の住民検診で胸部異常陰影を 指摘されたが，無症状のため放置していた，平成 9 年 7 月，咳濑、胸部不快感が出現した。住民検診で再度胸 部異常陰影を指摘され，增大していたため当院を紹介 された。

入院時現症：身長 $139 \mathrm{~cm}$, 体重 $63 \mathrm{~kg}$, 肥満体型で あった．血圧 $120 / 65 \mathrm{mmHg}$ ，脈拍 80 /分・整，胸部お よび腹部の理学的所見では異常は認められなかった。

入院時検查所見 : 血液生化学検查, 検尿, 腫湯マー カー, 肺機能検查, 血液ガス分析には異常所見は認め なかった．心電図で III 誘導に異常 Q 波,V $1 \sim$ V 6 に陰性 T 波および不完全右脚ブロックを認めた。 心工

1999 年 4 月 8 日受付 1999 年 10 月 8 日探用
コー検査では駆出分画が54\%と低下していた。

胸部 X 線写真：正面像では, 右心葴横隔膜角に境界 明瞭な手拳大の腫瘤影を認め (図 1 左), 側面像で陰影 は胸骨後部に存在し，右横隔膜のシルエットを一部消 失させていた（図 1 右)。

胸部 CT 写真：胸骨後部で心陰影の右側に接して脂 肪濃度の腫㿔影を認めた(図 2)．尾側スライスに移る につれて肝前面に同様の腫嘴影がみられ，両者連䄯し ている様に思われた（図3）。

胸部 MRI 写真：矢状断 T 1 强調画像で, 胸骨右縁 の断面では心膜と前胸壁と接して脂肪㜊度の腫瘤影を 認めた(图 4 左)．正中の断面では，その腫瘤影は横隔 膜の前方欠損部を通って腹腔内へ連続していた（図 4 右).胸腔内に消化管ガス像を認めないことより大網の みを内容とする Morgagni 孔へルニアが疑われたが， 縦隔腫瘍も完全には否定できなかったため，腫瘤影が 大網であるか否かを確認するため血管造影検查を施行 した。

血管造影所見：腹腔動脈造影を施行した，腫痹影へ 走行する右胃大網動脈の大網枝が確認できた(図 5).

以上より大網のみを内容とした Morgagni 孔へルニ アと診断，徐々に増大していることから手術適応とし た。

手術所見：上腹部正中切開にて開腹したところ，大 網が胸骨右後部の横隔膜欠損部より右胸腔内人入り込 


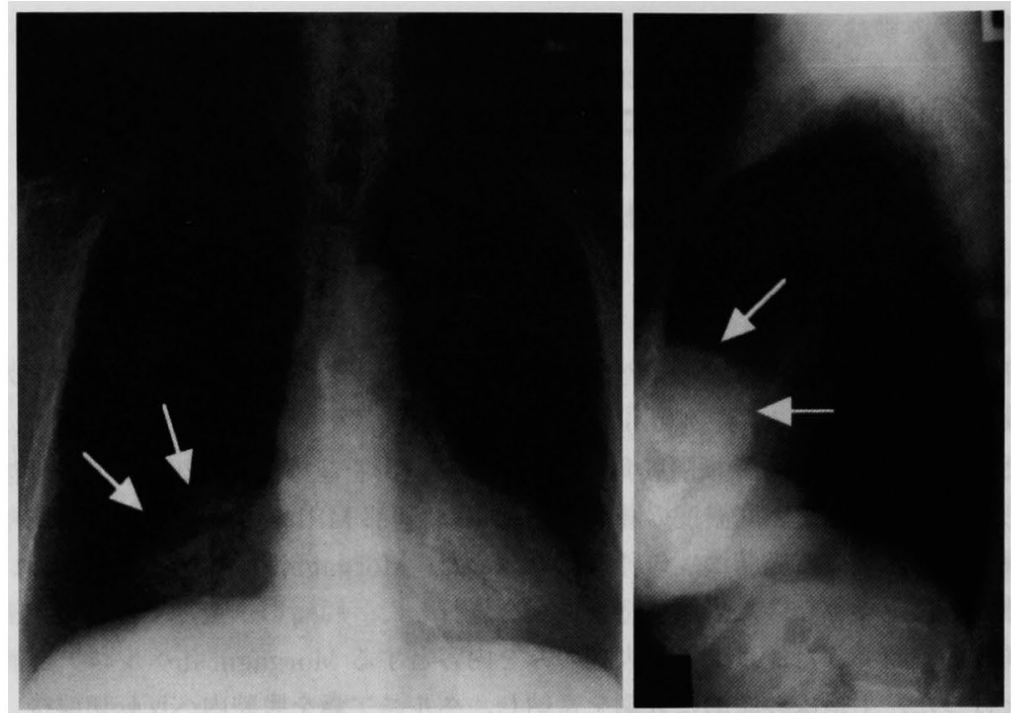

図 1 左, 胸部 X線（正面像）：右心葴横隔膜角に境界明暸な手拳大の腫瘤影を認め た。右, 胸部 X 線(側面像)：腫䟧影は胸骨後部に存在し，右横隔膜のシルエットを 一部消失させていた。

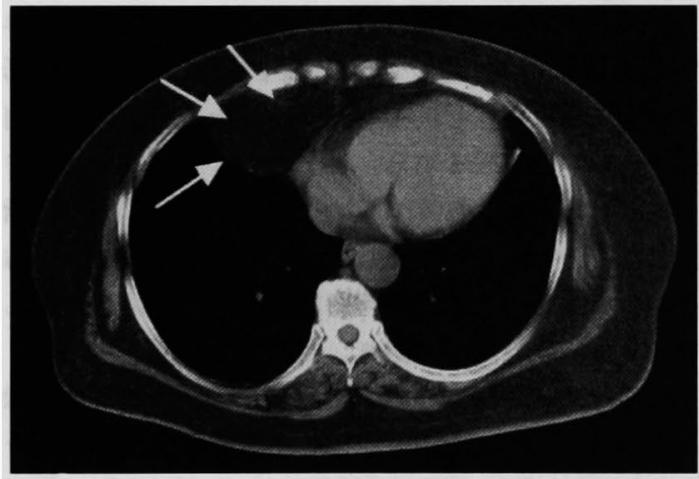

図 2 胸部 CT：胸骨後部で心陰影の右側に接して脂 肪溇度の腫瘤影を認めた。

んでいた(図6 左).大網を腹腔内へ還納後、ヘルニア 受を腹腔内に反転して切除した(図6右)。ヘルニア門 の大きさは, 約 $3 \times 4 \mathrm{~cm}$ で横隔膜を前胸壁に直接䋖合 閉鎖し手術を終了した.

術後経過：経過は良好で胸部 X 線上も異常影は消 失した。術後 2 週間で退院した。

\section{考察}

1769 年 Morgagni は剖検による横隔膜前部の欠損 を初めて報告した. Morgagni 孔へルニアは, 横隔膜の 胸骨付着部と肋骨付着部の間に存在する生理的に筋層

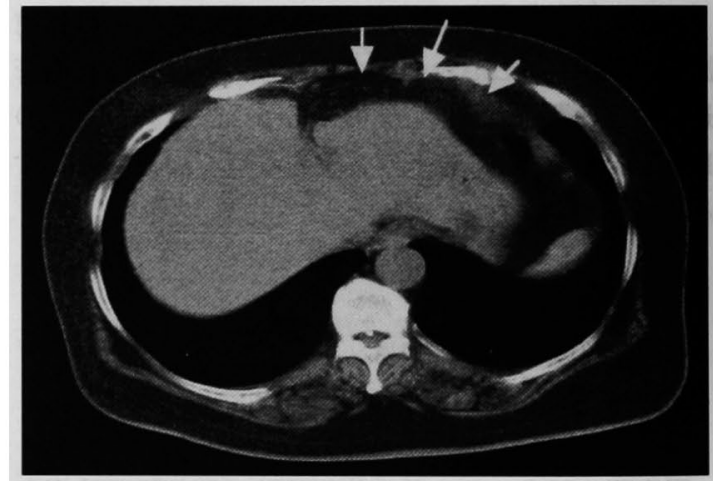

图 3 腹部 CT : 肝前面に脂肪濃度の腫嘴影がみられ た。

の乏しい抵抗脆弱部である胸肋三角に生ずるへルニア である゙．比較的稀な疾患で，全横隔膜へルニアの 2 〜3\%と報告されている゙'。

本症の発症年齡においては, 6 歳以下および 50 歳以 上に 2 つのピークがある゙．小児期での発症は, ほとん どが先天的なもので, その $40 \%$ に合併奇形を伴ってお り男児に多いのに对し，中高年龄者では压倒的に女性 に多く，その発症には肥満による腹圧の上昇，妊娠の 既往，加龄などの後天的要因による胸肋三角部の脆弱 化が関与していると考えられている゙! 


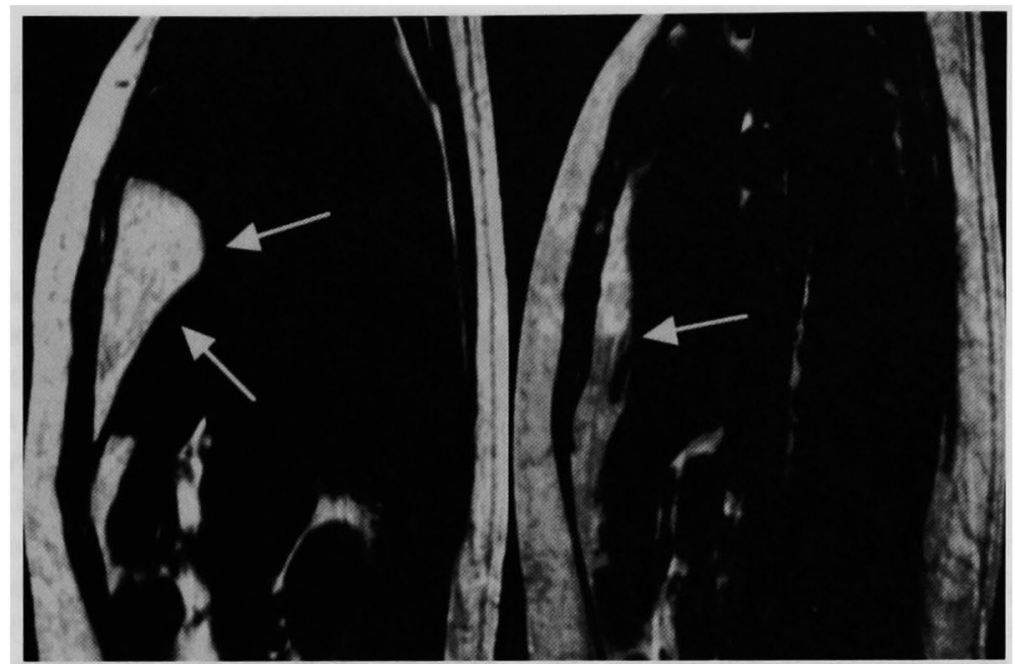

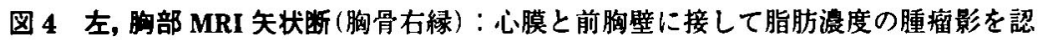
めた. 右, 胸部 MRI 矢状断（正中）：腫瘤影は横隔膜の前方欠損部を通って腹腔内 へ連続していた.

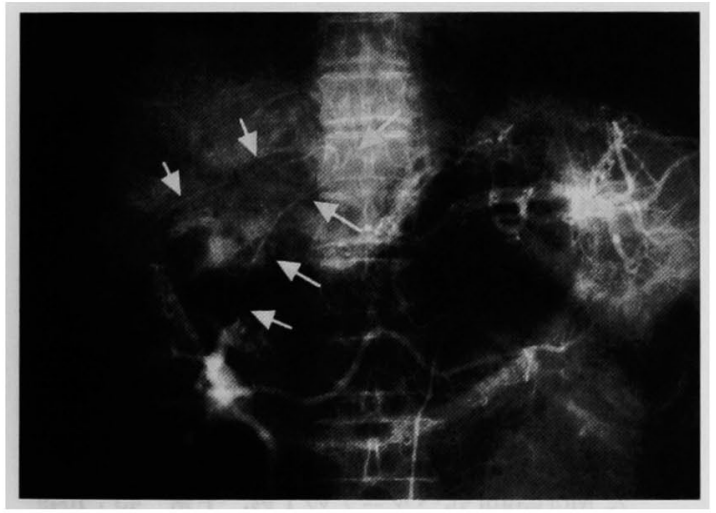

图 5 腹腔动脈造影：右胃大網動脈の大網枝より腫瘤 影への血流を認めた。

ヘルニア内容としては横行結腸, 大網, 肝, 小腸,

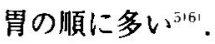

臨床症状は, 成人例においては腹痛, 䌿気, 嘔吐な どの消化器症状を呈することが多いが, 無症状で経過 し, 集団検診等で偶然発見されることも少なくない ${ }^{5 !}$.

一方, 乳児期では呼吸困難などの呼吸器症状を呈する ことが多い"，本症例では，当初は無症状であったが, ヘルニアの増大に伴って咳濑，胸部不快感などの呼吸 器症状が出現した。

診断は，ヘルニア内容が消化管の場合は，胸部単純 $\mathrm{X}$ 線写真で腫瘤影の中にガス像を認めるため容易であ
る.しかし，本症例の如く，大網のみを内容とした場 合, しばしば縦隔脂肪腫, 心膜豪腫, 肺腫瘍との鑑別 が重要となる. 鑑別診断法としては, 注腸造影, 腹部 血管造影, CT 検查, MRI 検査などが施行される. 大網 のみを内容とする症例の注腸造影では横行結腸の逆 V 字型偏位や固定を認めることがあり，また血管造影で は, 右胃大網動脈分枝の異常陰影内人の流入加確定 診断が得られることもある゙、また，CTやMRIによ る胸腹部の連続撮影が有用で, 腹腔内腫瘤陰影の腹腔 内からの脱出を確認することが重要であるとの報告も されている8).

本症例では, 術前の CT, MRI で, Morgagni 孔へル ニアが強く疑われたが確定診断に至らなかったため血 管造影検査を施行した. 右胃大䋧動脈分枝の異常陰影 内への走向がみられ, 確定診断が得られた。血管造影 は比較的低侵襲な検査で諸検査で確定診断に至らない 症例に対しては，積極的に考虑すべきであると思われ た.

手術適応については，無症状でも絞扼の危険性があ り，また自然治瘡の可能性もないことから全例手術適 応があるという意見が大多数である ${ }^{9101}$.

到達経路としては, 経胸法, 経腹法があり, それぞ れに長所を有し諸家の意見のわかれるところである. 経胸法の利点としては, 他の肺縦隔疾患が考えられる 場合でも，その対処が容易であることやヘルニア霰と 


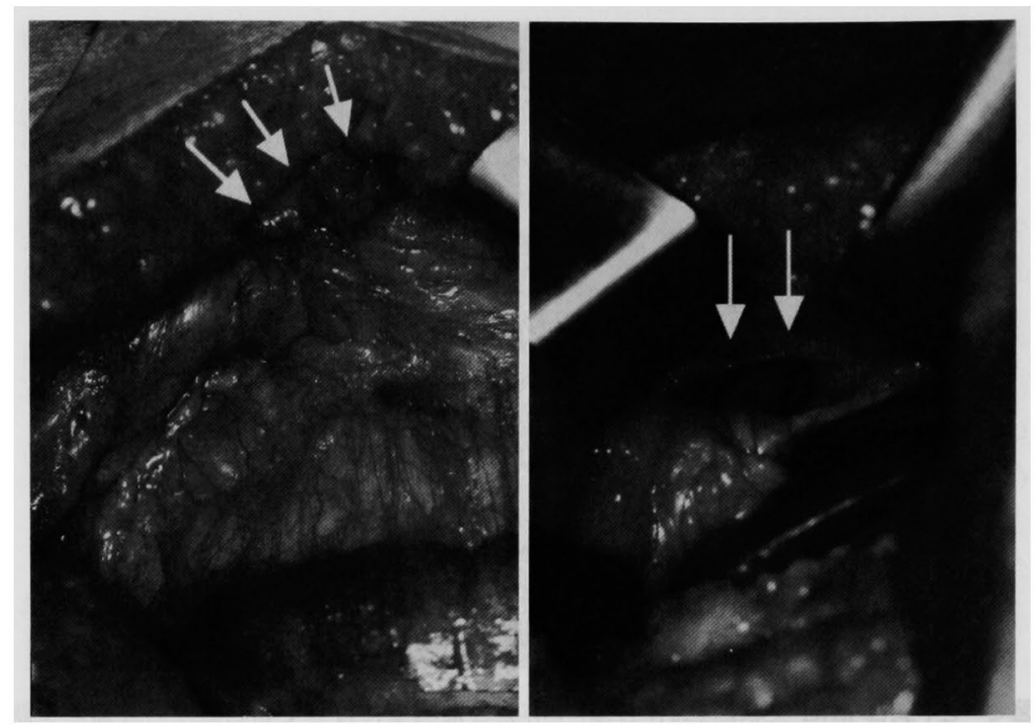

图 6 左, 術中写真：大網が胸骨右後部の横隔膜欠損部より右胸腔内人入り込んでい た. 右, 術中写真 : 右胸肋三角部に約 $3 \times 4 \mathrm{~cm}$ 大のヘルニア門を認めた.

胸腔内臟器が瘡着している場合に剥離が容易であるこ と，肥满者の場合でも手術が容易に行えることなどが あげられるの11)．経腹法では，呼吸機能への影響が少な いこと，ヘルニア門に近く左右どちらにも对処できる こと,ヘルニア内容を還納後の脱出臓器の状態を観察 できることが挙げられる12. ししし諸家の報告を総合 すると経胸法, 経腹法が大多数の例で行われておりそ の頻度はほほ同数である゙ .われわれは, 確定診断がつ かずに肺綎隔疾患が疑かれる場合は，胸㓐内を検索し うる経胸法を用い，確定診断がついている場合には経 腹法を用いるべきであると考えている，本疾患の病態 は腹腔内臓器の胸腔内脱出であり，ヘルニア内容の処 理や合併症の検索が可能であることなどを考えあわす と経腹法を選択すべきであると思われる．この点でも 術前に確定診断をしておく意義は高いと考えられる。

\section{結 語}

大網のみを内容とする Morgagni 孔ヘルニアの1例 を経験した，CT，MRIで疑診にとどまる症例に対し ては，血管造影検查が有用であると考えられた．以上， 若干の文献的考察を加え報告した。

\section{文献}

1) 師田 昇, 中岡 康：横隔膜ヘルニア. 呼吸 6 ： 595-600, 1987

2) 丸野 要, 加藤博司，二村 明他：Morgagni 孔へ ルニアの 2 治験例一本邦報告例及び成因について の検討一. 外科診療 $20: 349-353,1980$
3）井村賢治, 岡田 正, 鎌田振吉他：孚幼児 Morgagni 孔へルニアの 4 症例一本邦集計例の検討を 中心に一。少外科 $13: 799-808,1981$

4）北角泰人,下松谷匠, 堀内哲也他：イレゥス症状に より診断された Morgagni 孔へルニアの1例. 日 臨外医会誌 $58: 787-790,1997$

5）法化図陽一，有馬宽雄、井形昭弘他：Morgagni 孔ヘルニアの一症例と本邦報告例の文献的考察. 臨と研 $58: 1182-1186,1981$

6) 勝山新弥, 坂本 隆, 勝木茂美他：胃軸捻症を伴っ た成人 Larrey 孔へルニアの1例. 日消外会誌 $23: 2803-2807,1990$

7）宇都光伸, 上原景光, 久保博明他：術前に診断し之 た Morgagni 孔へルニアの1 例. 手術 $45: 1049$ $-1054,1991$

8）岩瀬芸和，河原啓治，小田修治他：MRIが術前診 断に有用であった Morgagni 孔ヘルニアの1例. 内科 $68: 383-386,1991$

9) Comer TP. Clagett OT : Surgical treatment of hernia of the foramen of Morgagni. J Thorac Cardiovasc Surg $52: 461-468,1966$

10）細井 順, 宮田道夫, 松沢裕一他：Morgagni 孔へ ルニアーその手術適応一。外科 $45: 1477-1481$, 1983

11）村山祐一郎, 神吉 豊, 中村昭光他：Morgagni 孔へルニアの 1 治験例と本邦報告例の検討. 胸部 外科 $35: 751-758,1982$

12）保坂 茂, 吉井新平, 高野邦夫他：大網を内容とし た Morgagni 孔ヘルニアの1例一とくにCTおよ び超音波検査の有用性と手術経路について一. 胸 部外科 $44: 503-506,1992$ 


\title{
A CASE OF MORGAGNI' FORAMEN HERNIA DIAGNOSED PREOPERATIVELY
}

\author{
Katsumi TAIRA, Noboru HIGA. Junko HIGA and Hiroshi SHIROMA \\ Department of Surgery. Tomishiro Chuo Hospital
}

A case of Morgagni's foramen hernia involving only the greater omentum which was preoperativery diagnosed by angiography is reported. A 64-year-old woman was referred to the hospital with a suspicion of having a mediastinal tumor at a mass screening medical examination. Chest $\mathbf{x}$-ray film revealed a fist-sized tumor shadow at a corner of diaphragm in the right heart. Chest CT visualized a tumor shadow of fat density adjacent to the right side of cardiac shadow behind the sternum. On sagittal plane of chest magnetic resonance imaging (MRI), a tumor shadow of fat density which was adjacent to the pericardium and anterior thoracic wall and communicated with the abdomen was confirmed. Morgagni's foramen hernia was suspected, but a possibility of mediastinal tumor could not be ruled out. So an angiography was performed and an omental branch of the right gastroepiploic artery along the tumor shadow was revealed. From these findings, the patient was diagnosed as having Morgagni's foramen hernia containing only the greater omentum and was operated on. At operation, the greater omentum was reduced by an abdominal approach, and the hernial openning was closed after the hernial sac was resected from the abdominal cavity. In the diagnosis of the disease, angiography is very valuable. 